\title{
PENGARUH STATUS GIZI IBU MENYUSUI TERHADAP EKSKLUSIVITAS ASI DAN PERTUMBUHAN BAYI DI RSUD PROF. DR. WZ JOHANNES KUPANG-NTT
}

\author{
Beatrix Soi ${ }^{1}$, Madarina Julia ${ }^{2}$, R. Dwi Budiningsari ${ }^{3}$
}

\begin{abstract}
Background : Numerous research have been made to find out contributive factors of the exclusive breastfeeding. Objective: The objective of this study was to find out whether mothers' nutritional status had any influence on the exclusivity of breastfeeding and on the growth of their babies up to 4 months.

Methods: This observational study was carried out with a prospective cohort design and lasted from November 2004 to May 2005. The subjects were 80 pairs of mother and baby treated at the Obstetric and Gynecology Unit (UPF) of Local Public Hospital (RSUD) Prof. Dr. W.Z. Johannes at Kupang - NTT. The subjects were divided into two groups namely Undernutrition status group marked by $<23,5 \mathrm{~cm}$ mid arm-circumference, and control group comprised 46 mothers of wellnutrition status who had bigger mid arm-circumference $\geq 23,5$ $\mathrm{cm}$. Observed babies were those of normal or spontaneous delivery, non twin with $>2500 \mathrm{~g}$ birth weight. Follow up observations were made at family home and the data on breastfeeding characteristics were collected by interview, babies weight were measured by Secca baby scale with $0,01 \mathrm{~kg}$ level of accuracy mid arm-circumference was measured by means of LILA tape, and body length was measured using length-board. Tools measure with 0,1 cm level of accuracy.

Some statistical tests were used namely Chi-Square; student's t-test; and while Kaplan Meier log-rank test as needed.

Results: More than $50 \%$ of under-nutrition mothers were under 25 years old. Chi-Square test shows that significant difference between mother's age was $(p=0,04)$. More than $50 \%$ of the KEK group gave birth for the first time or "primipara' $(p=0,25)$. Kaplan Meier analysis showed that there was no difference between survival median of breastfeeding between the both group $(p=0,53)$. $t$-test showed that there were significant differences of the babies body weight of the both KEK and non KEK mothers, namely pd"0,01, $p=0.01$, and $p=0.03$ in the first, second, third, and the fourth month respectively. In terms of the average babies body length, the $t$-test also showed significant differences between both groups with $p=0.02$ and $p=0.01$ in the third and the fourth month respectively.

Conclusion: I can be concluded that mother' nutrition status did not have any influence on the exclusivity of breastfeeding, however, it did significantly influence babies growth from 0 4 month.
\end{abstract}

Key words: Nutrition status, lactating mother, exclusive breastfeeding, baby's growth

\section{PENDAHULUAN}

Air susu ibu (ASI) sebagai makanan terbaik bagi bayi pada awal kehidupan untuk dapat tumbuh dan berkembang secara optimal. ASI juga mengandung zarzat imunologis yang bermanfaat bagi pencegahan infeksi terutama diare dan infeksi saluran pernapasan akut (1).

Berbagai upaya dilakukan untuk mempromosikan penggunaan ASI. UNICEF mencanangkan ASI eksklusif sebagai langkah untuk menurunkan angka kematian bayi (2). Hal yang sama dilakukan oleh WHO yang mengeluarkan rekomendasi untuk ASI eksklusif hingga bayi berusia 6 bulan dan menyebarkan 10 langkah menuju keberhasilan menyusui (3). Pemerintah Indonesia berupaya meningkatkan minat dan kesadaran masyarakat tentang pentingnya pemberian ASI melalui berbagai kegiatan seperti lomba bayi sehat, lomba klinik dan rumah sakit sayang bayi (4).

Walaupun kampanye tentang penggunaan ASI digalakkan di mana-mana, jumlah ibu yang memberikan ASI eksklusif belum menggembirakan. Pemerintah Indonesia menetapkan target cakupan $80 \%$ ASI eksklusif pada tahun 2010, namun jumlah ibu yang memberikan ASI cenderung menurun. Data SUSENAS tahun 1988 sebanyak $65 \%$ bayi kurang dari 4 (empat) bulan mendapat ASI eksklusif, pada tahun 2001 menurun menjadi 49,2\% (5). Hasil survei demografi dan kesehatan tahun 20022003 menunjukkan dari $96 \%$ bayi yang pernah disusui ibunya hanya $14 \%$ yang disusui secara eksklusif hingga berusia 5 hingga 6 bulan (6).

Berbagai penelitian dilakukan untuk menginvestigasi kegagalan pemberian ASI eksklusif. Pada umumnya berkurang atau tidak cukupnya produksi ASI menjadi salah satu alasan yang populer sebagai penyebab kegagalan pemberianASI eksklusif (7). Alasan-alasan di balik keluhan ASI kurang belum banyak diteliti. Status gizi ibu menyusui sebagai salah satu determinan pemberian ASI dan pertumbuhan bayi belum banyak diteliti. Dari beberapa penelitian yang dilakukan secara cross-sectional menunjukkan kejadian dini marasmus pada bayi dalam 6 bulan pertama kehidupan lebih

\footnotetext{
1 Politeknik Kesehatan Kupang NTT

2 Bagian Anak RS Dr. Sardjito/Fakultas Kedokteran UGM, Yogyakarta

3 Magister Gizi dan Kesehatan UGM, Yogyakarta
} 
banyak dialami oleh bayi-bayi dari ibu-ibu yang status gizinya jelek (8). Dari penelitian yang dilakukan di Madura didapatkan goncangan pertumbuhan yang terjadi pada bayi kurang dari 4 bulan akibat kurang asupan ASI karena ibu-ibu di Madura memulai laktasi dengan tidak cukup simpanan lemak selama kehamilan (5). Data profil kesehatan Propinsi Nusa Tenggara Timur tahun 2002 menggambarkan $42 \%$ ibu hamil di Kota Kupang menderita kekurangan energi kronik, 31\% wanita usia subur menderita kekurangan energi kronik. Balita yang mengalami gizi kurang sebanyak $27,4 \%$ dan gizi buruk sebanyak $2,92 \%$ dari total balita 7735 orang (9)

Penelitian ini dilakukan untuk mengetaui pengaruh status gizi ibu menyusui terhadap eksklusivitas ASI, dan pertumbuhan bayi di Kota Kupang.

\section{BAHAN DAN METODE}

Jenis penelitian ini observasional, dengan rancangan cohort prospective. Penelitian dilakukan sejak bulan Nopember 2004 hingga bulan Mei 2005. Pasangan ibu menyusui dan bayi yang lahir dan dirawat di ruang rawat gabung unit pelaksana fungsional (UPF) kebidanan dan kandungan RSUD Prof Dr. WZ Johanes Kupang diikuti hingga bayi berusia 4 bulan. Kriteria kelompok terpapar adalah lingkar lengan atas (LILA) ibu <23,5CM, sedangkan kelompok tidak terpapar lingkar lengan ibu $($ LILA) $\geq 23,5 \mathrm{~cm}$. Kriteria inklusi ibu adalah berdomisili di Kota Kupang, akan merawat bayinya sendiri dan bersedia ikut dalam penelitian. Kriteria inklusi bayi meliputi lahir aterm, spontan, berat badan lahir $\geq 2500$ gram, tidak gemeli dan skor apgar menit pertama 8-10. Kriteria eksklusi untuk ibu dan bayi adalah adanya keadaan patologis sehingga bayi tidak bisa diberi ASI.

Besar sampel ditetapkan sebanyak 88 orang yang terbagi menjadi 2 kelompok terdiri dari kelompok terpapar (ibu yang status gizinya kurang), dan kelompok tidak terpapar (ibu dengan status gizi baik).

Data karakteristik subjek dikumpulkan melalui wawancara dan dari rekam medis pasien. Data status gizi ibu menyusui diperoleh dengan mengukur lingkar lengan atas (LILA) dan data pertumbuhan bayi diperoleh dengan menimbang berat badan dan mengukur panjang badan bayi selama 24 jam pertama setelah lahir dilanjutkan dengan pengukuran secara berkala sebulan sekali hingga bayi berusia 4 (empat) bulan di rumah. Data eksklusivitas ASI diperoleh dengan cara pengamatan terhadap pola inisisasi ASI di rumah sakit dilanjutkan dengan follow-up sebulan sekali hingga bayi berusia 4 (empat) bulan.

Karakteristik responden diolah dengan menggunakan program statistik komputer dan di analisis dengan uji Chisquare, sedangkan data eksklusivitas ASI dianalisis menggunakan uji log-rank dan analisis Kaplan Meier (10).
Data Pertumbuhan bayi dianalisis dengan uji t, dan data pengaruh status gizi ibu terhadap pertumbuhan bayi dianalisis stratifikasi berdasarkan status laktasi (eksklusif dan noneksklusif) dengan uji t.

\section{HASIL DAN BAHASAN}

Dari 92 subjek yang memenuhi kriteria inklusi, hanya 80 subjek yang di follow-up lanjutan hingga penelitian selesai, dengan rincian 34 subjek dengan status gizi ibu kurang dan lingkar lengan kurang dari $23,5 \mathrm{~cm}$, dan 46 subjek dengan status gizi baik dan lingkar lengan $\geq 23,5 \mathrm{~cm}$. Pada dasarnya karakteristik subjek homogen, tidak ada perbedaan secara signifikan ( $p>0,05)$, namun pada data umur responden didapatkan perbedaan secara bermakna $(p=0,04)$. Dilihat dari data frekuensi melahirkan, mayoritas responden dari status gizi baik melahirkan lebih dari 1 kali, sedangkan subjek yang status gizinya kurang lebih dari separuhnya baru pertama kali melahirkan atau primipara (Tabel 1).

Data karakteristik bayi dari kedua kelompok tidak banyak berbeda. Hal ini terjadi, oleh karena subjek penelitian diambil yang hamil aterm dengan usia kehamilan lebih $\geq 38$ minggu, berat badan lahir $\geq 2500$ gram (Tabel 2).

Status gizi ibu menyusui sebagai determinan keberhasilan menyusui, belum ada penelitian yang membuktikannya. Dalam penelitian ini tidak didapatkan perbedaan median survival $50 \%$ antara kedua kelompok dengan Log Rank Test $(p=0,53)$. Ada tendensi ibu dengan status gizi baik proporsi pemberian ASI eksklusif lebih tinggi (Gambar 1). Beberapa faktor karakteristik seperti umur dan paritas yang sudah dijabarkan sebelumnya dapat mendukung penjelasan ini.

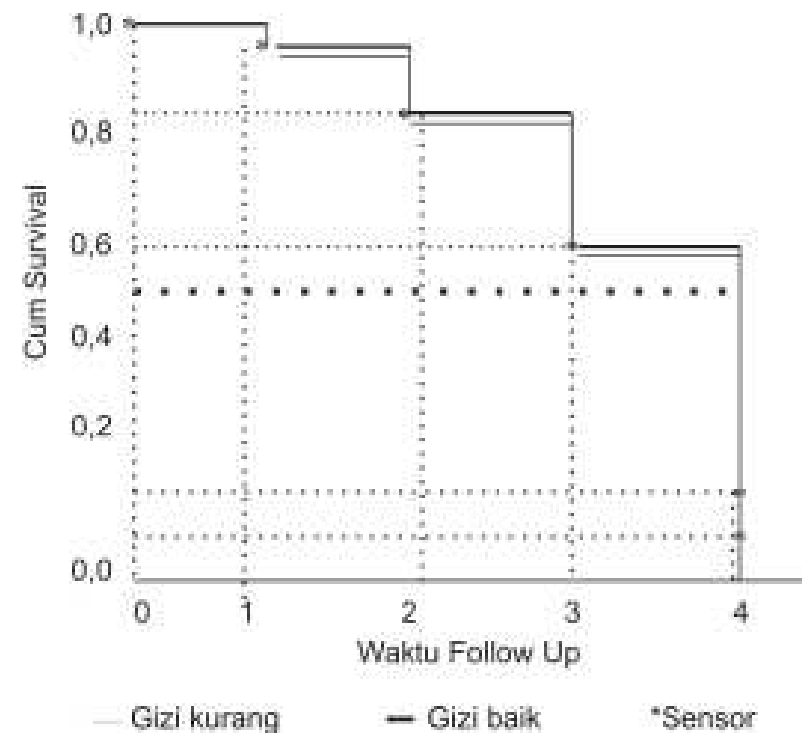

GAMBAR 1. Pengaruh status gizi ibu menyusui terhadap eksklusivitas ASI 
TABEL 1. Karakteristik ibu

\begin{tabular}{|c|c|c|c|}
\hline \multirow{3}{*}{ Variabel } & \multicolumn{2}{|c|}{ Status gizi ibu menyusui } & \multirow{3}{*}{$\mathbf{p}$} \\
\hline & Gizi kurang & Gizi baik & \\
\hline & $(n=34)$ & $(n=46)$ & \\
\hline \multicolumn{4}{|l|}{ Umur Ibu } \\
\hline$<25$ tahun & $17(50 \%)$ & $9(19,6 \%)$ & $0,04^{a b}$ \\
\hline$\geq 25$ tahun & $17(50 \%)$ & $37(80,4 \%)$ & \\
\hline \multicolumn{4}{|l|}{ Pendidkan } \\
\hline$\leq \mathrm{SMP}$ & $9(26,5 \%)$ & $13(28,3 \%)$ & $0,86^{a}$ \\
\hline$\geq$ SMA & $25(73,5 \%)$ & $33(71,7 \%)$ & \\
\hline \multicolumn{4}{|l|}{ Pekerjaan } \\
\hline Ibu rumah tangga & $21(61,8 \%)$ & $28(60,9 \%)$ & $0,94^{a}$ \\
\hline Bekerja & $13(38,2 \%)$ & $18(39,1 \%)$ & \\
\hline \multicolumn{4}{|l|}{ Paritas } \\
\hline 1 & $18(52,9 \%)$ & $13(28,3 \%)$ & $0,25^{\mathrm{a}}$ \\
\hline$>1$ & $16(47,1 \%)$ & $33(71,7 \%)$ & \\
\hline
\end{tabular}

Keterangan:

a Uji Chi-square.

${ }^{\mathrm{b}}$ Signifikan $(p>0,05)$

Beberapa keluhan yang menjadi alasan sehingga bayi tidak diberikan ASI eksklusif antara lain keluhan air susu kurang, takut bayi demam atau kuning, hanya menggunakan salah satu sisi payudara. Keluhan takut bayi demam atau kuning datang dari tenaga kesehatan, sedangkan salah satu sisi payudara tidak mengeluarkan ASI datang dari ibu-ibu primipara. Keluhan ini timbul pada usia bayi lebih dari 2 bulan, karena ibu-ibu cenderung memberikan ASI hanya dari salah satu payudara (Tabel 3 ). stratifikasi untuk melihat kemungkinan pengaruh status gizi ibu terhadap pertumbuhan bayi, merupakan efek modifikasi status lakstasi (Tabel 6,7).

\section{Karakteristik Subjek}

Dalam budaya Indonesia, usia 25 tahun masih belum mandiri,masih di bawah dominasi orangtua atau suami. Dalam masyarakat patrilineal dengan mas kawin yang

TABEL 2. Karakteristik bayi

\begin{tabular}{|c|c|c|c|c|}
\hline \multirow[b]{2}{*}{ Variabel } & \multicolumn{2}{|c|}{ Kelompok Buketi } & \multirow[b]{2}{*}{$\begin{array}{l}\text { Mean perbedaan } \\
\text { (KI 95\%) }\end{array}$} & \multirow[b]{2}{*}{$\mathbf{p}$} \\
\hline & $\begin{array}{c}\text { Gizi kurang } \\
\text { Mean } \pm \text { SD } \\
\end{array}$ & $\begin{array}{c}\text { Gizi baik } \\
\text { Mean } \pm \text { SD } \\
\end{array}$ & & \\
\hline BBL & $2,97 \pm 0,33$ & $3,06 \pm 0,31$ & $-0,09(0,04-0,24)$ & $0,18^{*}$ \\
\hline PBL & $47.61 \pm 1,57$ & $47,65 \pm I, 77$ & $-0,03(0,72-0,79)$ & $0,92^{*}$ \\
\hline Usia kehamilan & $40,68 \pm 1,68$ & $40,20 \pm 0,98$ & $0,48(0,11-1.07)$ & $0,11^{*}$ \\
\hline Skor Apgar & $8,15 \pm 0,35$ & $8,07 \pm 0,25$ & $-0,08(0,05-0,21)$ & $0,23^{*}$ \\
\hline Ponderal Index & $27,59 \pm 3,15$ & $28,42 \pm 3,52$ & $0,82(0,69-2,34)$ & $0,28^{*}$ \\
\hline
\end{tabular}

Keterangan:

* Uji t

$\mathrm{BBL}=$ Berat badan lahir

$\mathrm{PBL}=$ Panjang badan lahir.

Pada penelitian ini, pengaruh status gizi ibu terhadap berat badan bayi berbeda secara bermakna $(p<0,05)$ sejak usia bayi 1 bulan (Tabel 4).

Selain indikator berat badan, panjang badan bayi dalam penelitian ini menunjukkan perbedaan secara bermakna. Hasil uji t menunjukkan pada bulan ke 3 nilai $p=0,029$, pada bulan ke 4 nilai $p<0,001$ (Tabel 5).

Setelah dilakukan uji t untuk melihat pengaruh status gizi ibu terhadap pertumbuhan bayi, dilakukan analisis tinggi, anak perempuan tinggal bersama mertua. Determinan kegagalan laktasi tidak hanya asupan makanan atau status gizi, namun merupakan kombinasi berbagai faktor termasuk tekanan psikososial. Pada ibu yang mengalami stress, refleks let-down terblokir menyebabkan volume ASI berkurang (8). Dikatakan usia di atas 35 tahun lebih berhasil memberikan ASI (11). Dalam penelitian lain didapatkan ibu-ibu yang berusia 20 24 tahun lebih suka memberikan ASI eksklusif (12). 
TABEL 3. Beberapa alasan ASI tidak eksklusif

\begin{tabular}{|c|c|c|c|}
\hline \multirow[b]{2}{*}{ Bulan } & \multirow[b]{2}{*}{ Alasan } & \multicolumn{2}{|c|}{ Status gizi ibu menyusui } \\
\hline & & $\begin{array}{c}\text { Gizi kurang } \\
(n-34)\end{array}$ & $\begin{array}{c}\text { Gizi baik } \\
(n-46)\end{array}$ \\
\hline I & $\begin{array}{l}\text { Jumlah tidak eksklusif } \\
\text { Disuruh petugas } \\
\text { Takut bayi demam/kuning }\end{array}$ & $\begin{array}{l}9 \text { orang } \\
6(66,7 \%) \\
3(33,3 \%)\end{array}$ & $\begin{array}{l}10 \text { orang } \\
5(50 \%) \\
5(50 \%)\end{array}$ \\
\hline II & $\begin{array}{l}\text { Jumlah tidak eksklusif } \\
\text { ASI kurang, bayi rewel } \\
\text { Bekerja/kuliah }\end{array}$ & $\begin{array}{l}12 \text { orang } \\
5(41,6 \%) \\
7(58,4 \%)\end{array}$ & $\begin{array}{l}16 \text { orang } \\
6(37,3 \%) \\
10(62,7 \%)\end{array}$ \\
\hline III & $\begin{array}{l}\text { Jumlah tidak eksklusif } \\
\text { ASI kurang, bayi rewel } \\
\text { Bekerja/kuliah } \\
\text { Susu hanya sebelah }\end{array}$ & $\begin{array}{l}18 \text { orang } \\
7(38,9 \%) \\
7(38,9 \%) \\
4(22,2 \%)\end{array}$ & $\begin{array}{c}27 \text { orang } \\
11(40,7 \%) \\
13(48,2 \%) \\
3(11,1 \%)\end{array}$ \\
\hline IV & $\begin{array}{l}\text { Jumlah tidak eksklusif } \\
\text { ASI kurang, bayi rewel } \\
\text { Bekerja/kuliah } \\
\text { Susu hanya sebelah }\end{array}$ & $\begin{array}{c}26 \text { orang } \\
15(57,7 \%) \\
7(26,9 \%) \\
4(15,4)\end{array}$ & $\begin{array}{c}28 \text { orang } \\
12(42,9 \%) \\
13(46,4 \%) \\
3(10,7 \%)\end{array}$ \\
\hline
\end{tabular}

Dalam hubungannya dengan frekuensi melahirkan, dilaporkan bahwa ibu-ibu primipara menunjukkan cara menyusui tidak tepat, hal ini diperparah oleh pemberian susu formula dengan menggunakan dot/botol (13).

\section{Karakteristik Bayi}

Pengaruh status gizi ibu hamil terhadap berat badan lahir sudah dibuktikan dari berbagai penelitian. Retardasi pertumbuhan secara simetris (stunting IUGR) bila

TABEL 4. Rata- rata pertumbuhan bayi berdasarkan berat badan bayi hingga usia 4 bulan

\begin{tabular}{|c|c|c|c|c|c|}
\hline \multirow{3}{*}{$\begin{array}{l}\text { Usia } \\
\text { (bulan) }\end{array}$} & \multicolumn{2}{|c|}{ Status gizi ibu menyusui } & \multirow{3}{*}{$\begin{array}{c}\text { Mean } \\
\text { perbedaan } \\
\text { BB }(\mathbf{k g}) \\
(\mathrm{IK}=95 \%)\end{array}$} & \multirow{3}{*}{$\mathbf{t}$} & \multirow{3}{*}{$\mathbf{p}$} \\
\hline & $\begin{array}{c}\text { Gizi kurang } \\
(n=34)\end{array}$ & $\begin{array}{c}\text { Gizi baik } \\
(n=46)\end{array}$ & & & \\
\hline & $\begin{array}{c}\text { Mean BB(kg) } \\
\pm \text { SD }\end{array}$ & $\begin{array}{l}\text { Mean BB(kg) } \\
\pm \text { SD }\end{array}$ & & & \\
\hline 0 & $2,97 \pm 0,33$ & $3,06 \pm 0,31$ & $-0,09(-0,24 ;-0,04)$ & $-1,32$ & 0,18 \\
\hline 1 & $3,53 \pm 0,46$ & $3,93 \pm 0,37$ & $-0,39(-0,58 ;-0,20)$ & $-4,16$ & $<0,001^{*}$ \\
\hline 2 & $4,33 \pm 0,, 58$ & $4,76 \pm 0,48$ & $-0,43(-0,67 ;-0,19)$ & $-3,62$ & $0,01^{*}$ \\
\hline 3 & $5,04 \pm 0,66$ & $5,48 \pm 0,53$ & $-0,44(-0,70 ;-0,17)$ & $-3,30$ & $0,01^{*}$ \\
\hline 4 & $5,64 \pm 0,78$ & $5,99 \pm 0,61$ & $-0,34(-0,66 ;-0,03)$ & $-2,20$ & $0,03^{*}$ \\
\hline
\end{tabular}

Keterangan:

* Signifikan $(p<0,05)$

TABEL 5. Rata-rata pertumbuhan bayi berdasarkan panjang badan hingga bayi berusia 4 bulan

\begin{tabular}{|c|c|c|c|c|c|}
\hline \multirow{3}{*}{$\begin{array}{l}\text { Usia } \\
\text { (bulan) }\end{array}$} & \multicolumn{2}{|c|}{ Status gizi ibu menyusui } & \multirow{3}{*}{$\begin{array}{l}\text { Mean } \\
\text { perbedaan } \\
(\mathrm{IK}=95 \%) \\
\mathrm{PB}(\mathrm{CM})\end{array}$} & \multirow{3}{*}{$\mathbf{T}$} & \multirow{3}{*}{$\mathbf{p}$} \\
\hline & $\begin{array}{c}\text { Gizi kurang } \\
(n=34)\end{array}$ & $\begin{array}{c}\text { Gizi baik } \\
(n=46)\end{array}$ & & & \\
\hline & $\begin{array}{c}\text { Mean PB }(\mathrm{cm}) \\
\pm \mathrm{SD}\end{array}$ & $\begin{array}{c}\text { Mean PB }(\mathrm{cm}) \\
\pm \text { SD }\end{array}$ & & & \\
\hline 0 & $47,61 \pm 1,57$ & $47,65 \pm 1,77$ & $-0,03(-0,79-0,72)$ & $-0,09$ & 0,9 \\
\hline 1 & $51,08 \pm 1,84$ & $50,83 \pm 2,20$ & $0,24(-0,68 ;-1,17)$ & 0,52 & 0,6 \\
\hline 2 & $54,81 \pm 8,53$ & $57,10 \pm 1,74$ & $-2,28(-4,85 ;-0,28)$ & $-1,77$ & 0,08 \\
\hline 3 & $58,76 \pm 1,47$ & $59,56 \pm 1,68$ & $-0,80(-1,52 ;-0,08)$ & $-2,22$ & $0,02^{*}$ \\
\hline 4 & $61,56 \pm 2,29$ & $63,37 \pm 1,97$ & $-1,80(-2,75 ;-0,85)$ & $-3,77$ & $<0,001^{*}$ \\
\hline
\end{tabular}

Keterangan:

* Signifikan $(p<0,05)$

$\mathrm{PB}=$ panjang badan. 
TABEL 6. Analisis stratifikasi pengaruh gizi ibu menyusui terhadap berat badan bayi yang diberi ASI eksklusif

\begin{tabular}{ccccccccc}
\hline \multirow{2}{*}{$\begin{array}{c}\text { Usia bayi } \\
\text { (bulan) }\end{array}$} & $\mathbf{n}$ & $\begin{array}{c}\text { Gizi kurang } \\
\text { Mean BB (kg) } \\
\mathbf{\pm} \text { SD }\end{array}$ & $\mathbf{n}$ & $\begin{array}{c}\text { Sizi baik } \\
\text { Mean BB (kg) } \\
\mathbf{\pm} \text { SD }\end{array}$ & & $\begin{array}{c}\text { Mean } \\
\text { perbedaan } \\
\mathbf{B B}(\mathbf{k g}) \mathbf{( I K ~ 9 5 \% )}\end{array}$ & $\mathbf{t}$ & $\mathbf{p}$ \\
\hline 1 & 25 & $3,60 \pm 0,48$ & 36 & $3,98 \pm 0,35$ & $-0,38(-0,61 ;-0,14)$ & $-3,29$ & $0,002^{*}$ \\
2 & 22 & $4,37 \pm 0,60$ & 30 & $4,84 \pm 0,45$ & $-0,46(-0,76 ;-0,17)$ & $-3,18$ & $0,003^{*}$ \\
3 & 16 & $5,03 \pm 0,65$ & 19 & $5,58 \pm 0,42$ & $-0,55(-0,93 ;-0,17)$ & $-2,94$ & $0,006^{*}$ \\
4 & 8 & $5,35 \pm 0,65$ & 18 & $6,12 \pm 0,64$ & $-0,77(-1,34 ;-0,20)$ & $-2,81$ & $0,01^{*}$ \\
\hline
\end{tabular}

Keterangan:

* Signifikan $(p<0,05)$

$\mathrm{BB}=$ berat badan

TABEL 7. Analisis stratifikasi pengaruh status gizi ibu menyusui terhadap berat badan bayi yang diberi ASI tidak eksklusif

\begin{tabular}{|c|c|c|c|c|c|c|c|}
\hline \multirow[b]{2}{*}{$\begin{array}{c}\text { Usia } \\
\text { bayi } \\
\text { (bulan) }\end{array}$} & \multicolumn{4}{|c|}{ Status gizi ibu menyusui } & \multirow[b]{2}{*}{$\begin{array}{c}\text { Mean } \\
\text { perbedaan } \\
\text { BB(IK 95\%) }\end{array}$} & \multirow[b]{2}{*}{$\mathbf{t}$} & \multirow[b]{2}{*}{$\mathbf{p}$} \\
\hline & $\mathbf{n}$ & $\begin{array}{c}\text { Gizi baik } \\
\text { Mean BB (kg) } \\
\pm \text { SD }\end{array}$ & $\mathbf{n}$ & $\begin{array}{c}\text { Gizi kurang } \\
\text { Mean BB (kg) } \\
\pm \text { SD } \\
\end{array}$ & & & \\
\hline 1 & 9 & $3,56 \pm 0,40$ & 10 & $3,89 \pm 0,48$ & $-0,53(-0,97 ;-0,09)$ & $-2,58$ & $0,01^{*}$ \\
\hline 2 & 12 & $4,25 \pm 0,55$ & 16 & $4,65 \pm 0,52$ & $-0,36(-0,78 ;-0,05)$ & $-1,78$ & 0,08 \\
\hline 3 & 18 & $5,10 \pm 0,68$ & 27 & $5,45 \pm 0,59$ & $-0,35(-0,75 ; 0,04)$ & $-1,81$ & 0,07 \\
\hline 4 & 26 & $5,72 \pm 0,81$ & 28 & $5,88 \pm 0,60$ & $-0,15(-0,55 ; 0,24)$ & $-0,77$ & 0,44 \\
\hline
\end{tabular}

Keterangan:

* Signifikan $(p<0,05)$

$\mathrm{BB}=$ berat badan

didapatkan berat badan, panjang badan dan lingkar kepala tidak sesuai umur kehamilan dan di bawah persentil ke-10, terjadi sebagai kibat gangguan pada awal kehamilan. Sedangkan retardasi pertumbuhan tidak simetris/ Wasted Intra Utirine Growth Retardation (IUGR) bila panjang badan dan lingkar kepala normal, namun berat badan lahir tidak sesuai umur kehamilan, sebagai akibat gangguan fungsi plasenta yang terjadi pada trimester terakhir kehamilan $(14,15)$.Dikatakan bahwa asupan energi dan protein pada akhir kehamilan berhubungan secara negatif dengan indeks ponderal bayi baru lahir. Asupan energi dari protein susu sangat berhubungan dengan berat badan lahir dan indeks ponderal dari pada protein bersumber makanan lain (16).

\section{Alasan-Alasan ASI Tidak Eksklusif}

Bila bayi tidak sering disusui, tidak ada stimulus terhadap reflex let-down, produksi ASI menjadi sedikit bahkan berhenti (17). Selain alasan-alasan yang tertera pada Tabel 3, kemungkinan adanya akumulasi dari alasan-alasan lain perlu digali lebih mendalam.
Pengaruh Status Gizi Ibu terhadap Pertumbuhan Bayi (Berat Badan Bayi)

Hubungan status gizi ibu terhadap pertumbuhan bayi dapat dilihat dari beberapa aspek dan hasil penelitian para ahli dalam masalah ini.

Kelenjar mammae sering disebut sebagai plasenta ekstra uterine karena menggantikan fungsi plasenta dalam mensuplai kebutuhan nutrisi bagi bayi (18). Perbedaannya, plasenta intra uterine mensuplai kebutuhan janin secara langsung, sehingga bila cadangan lemak tubuh memadai, pertumbuhan janin tidak mengalami hambatan. Pemberian ASI sudah melibatkan hubungan interaktif ibu dan bayi. Perilaku ibu dalam pemberian ASI menentukan pertumbuhan bayi.

Dari penelitian-penelitian sebelumnya, para ahli menyimpulkan, bahwa cadangan lemak tubuh selama hamil sebanyak $\pm 4 \mathrm{~kg}$ atau $1 / 3$ bagian dari seluruh kenaikan berat badan ibu hamil, cukup untuk cadangan $35000 \mathrm{kkal}$ yang dapat mensuplai $300 \mathrm{kkal}$ per hari untuk bayi selama 3 hingga 4 bulan. Yang menjadi masalah, ibu-ibu di negara miskin memiliki cadangan lemak tubuh 
yang rendah saat sebelum hamil. Peningkatan berat badan selama hamil jauh di bawah berat badan ibu-ibu di negaranegara barat. Ibu-ibu di negara barat mengalami kenaikan berat badan hingga $12,5 \mathrm{~kg}$, sedangkan di negara-negara miskin hanya separuhnya (8). Beberapa penelitian yang menggambarkan pengaruh status gizi ibu terhadap pertumbuhan antara lain, penelitian di Karachi dan Pakistan menunjukkan kejadian marasmus dini dalam 6 bulan pertama pada bayi yang masih disusui, terjadi pada ibuibu dengan status gizi buruk terutama pada musim paceklik, sebab volume ASI menurun 100-200 ml/hari (8).

Penelitian di Pedesaan Kenya menunjukkan produksi ASI per hari pada ibu-ibu dengan indeks masa tubuh rendah sebanyak 695 gram, sedangkan ibu-ibu dengan berat badan normal, produksi ASI-nya $790 \mathrm{~g}$ (19). Hasil penelitian terakhir di Kenya menujukkan ibu-ibu memulai laktasi dengan cadangan lemak sedikit. Dikatakan walaupun asupan energi memadai selama menyusui, tidak cukup untuk memelihara integritas tubuh dan aktivitas sehari-hari, apalagi untuk memproduksi ASI agar pertumbuhan bayi secara optimal. Dilaporkan juga bahwa pemberian makanan secara dini sebelum bayi berusia 6 bulan, merupakan prediktor berat badan bayi yang rendah di Kenya (20).

Di Indonesia, penelitian terhadap ibu-ibu menyusui di Madura, menunjukkan goncangan pertumbuhan bayi dalam 4 bulan pertama kehidupan terjadi karena ibu-ibu memulai masa laktasi dengan cadangan lemak tidak memadai (5). Penelitian lain dilakukan oleh Pusat Penelitian dan Pengembangan Gizi Bogor, ibu-ibu yang memiliki balita gizi kurang memiliki cadangan lemak (yang diukur dengan lingkar lengan atas) lebih kecil dari ibu-ibu yang memiliki balita dengan status gizi baik (21).

Cadangan lemak pada ibu-ibu KEK tidak mencukupi kebutuhan $110 \mathrm{kkal} / \mathrm{kg}$ bb/hari, atau kurang dari angka kecukupan gizi 560 kkal yang dianjurkan pemerintah Indonesia untuk bayi berusia kurang dari 5 bulan (22), karena mereka memulai laktasi dengan cadangan lemak yang rendah. Faktor lain yang tidak secara langsung mempengaruhi adalah faktor iklim dan musim. Pada bulan Januari dan Februari, pada musim hujan, para nelayan tidak menangkap ikan karena gelombang. Pada saat itu ikan menjadi mahal dan tidak terjangkau oleh kelompok ekonomi lemah. Di sisi lain kurangnya curah hujan di hampir seluruh wilayah Nusa Tenggara Timur, menyebabkan gagal panen yang berpengaruh terhadap harga kebutuhan pokok.

\section{Pengaruh Status Gizi Ibu terhadap Pertumbuhan Bayi (Panjang Badan Bayi)}

Bila melihat data pengaruh status gizi ibu terhadap eksklusivitas, kelompok gizi baik lebih banyak yang memberikan ASI eksklusif. Hal ini dapat terjadi karena, walaupun kadar kalsium ASI lebih rendah dari susu sapi, penyerapan kalsium ASI lebih efektif $67 \%$ dibandingkan dengan $25 \%$ dari susu sapi. Kadar zat besi dalam ASI rendah namun dapat diserap hingga $50 \%$ dibandingkan dari susu sapi hanya 10\% yang diserap (20). Hasil penelitian terakhir di Senegal, anak usia 3 tahun yang diberi ASI dalam jangka waktu lebih lama, panjang badan atau/length increments lebih dari anak yang mengkonsumsi susu formula dan disapih lebih awal (23).

\section{Status Laktasi sebagai Modifikasi Efek Pengaruh Status Gizi Ibu terhadap Pertumbuhan Bayi}

Hasil uji t menunjukkan tidak ada perbedaan secara bermakna baik pada kelompok KEK maupun kelompok non-KEK. Namun bila kita amati, baik pada kelompok KEK maupun non-KEK, ada kecenderungan bayi yang diberi ASI eksklusif rata-rata berat badan lebih dari yang ASI tidak eksklusif. Hasil study DARLING (Davis Area Research on Lactation, Infant Nutrition and Growth) pada 3 bulan pertama kehidupan tidak didapatkan perbedaan pertumbuhan antara bayi yang diberi ASI dan susu formula. Namun akumulasi pertumbuhan pada usia 1 tahun berat badan bayi yang mengkonsumsi susu formula lebih dari yang mengkonsumsi ASI dengan perbedaan 0,65 kg (24). Namun hasil analisis survei gizi dan Kesehatan antara tahun 1988 sampai tahun 1994 di Amerika Serikat bayi yang diberi ASI berat badannya lebih $100 \mathrm{~g}$ dari yang diberi susu formula (11).

\section{KESIMPULAN DAN SARAN}

Dalam penelitian ini ibu-ibu yang status gizinya baik lebih banyak yang memberikan ASI eksklusif (13,3\%) dibanding kelompok ibu dengan status gizi kurang $(7,5 \%)$.

Pertumbuhan bayi dari ibu-ibu yang status gizinya baik lebih baik dari bayi yang ibunya mengalami gizi kurang. Pertumbuhan bayi yang diberi ASI eksklusif lebih baik dari yang tidak diberi ASI eksklusif.

Perlu penyuluhan kesehatan tentang gizi dan ASI eksklusif kepada ibu-ibu sejak masa hamil agar ibu-ibu cukup mengkonsumsi makanan bergizi dan memiliki rasa percaya diri untuk memberikan ASI secara eksklusif. Karena dengan memberikan ASI bayi dapat tumbuh dan berkembang secara optimal dan terhindar dari penyakit infeksi.

Instansi-instansi pemerintah maupun swasta dapat menyiapkan tempat penitipan bayi (day care) agar bayi dari ibu-ibu bekerja dapat diberikan ASI sesuai kebutuhan.

\section{Ucapan Terima Kasih}

Ucapan terima kasih disampaikan kepada Kepala Dinas Kesehatan Propinsi Nusa Tenggara Timur yang 
menyediakan dana hingga penelitian ini dapat dirampungkan. Ucapan terima kasih juga disampaikan kepada Direktur RSUD Prof. Dr. WZ. Johannes yang memberikan izin dan memberikan data-data untuk terlaksananya penelitian ini.

\section{RUJUKAN}

1. Lawrence RA. Breast-Feeding, a Guide for The Medical Profession. St.Louis, Toronto, London:The Mosby Company; 1980.

2. Gillespie S, Milla MC, Roger S, editors. Combatting Malnutrition. The World Bank; 2003.

3. World Health Organization. Evidence for the Ten Steps to Successful Breastfeeding. WHO/CHD/98.9; 1998.

4. Soetjiningsih, editors. Asi Petunjuk untuk Tenaga Kesehatan, Seri Gizi Klinis. Jakarta: EGC; 1997.

5. Irawati A, Widodo Y, Triwinarto A. Asi Eksklusif: Status Kini dan Harapan di Masa Depan. Prosiding Konas XII Persagi; 2002.

6. Badan Pusat Statistik Nasional. Survey Demografi dan Kesehatan Nasional, 2002-2003.

7. Moore K, Chute G. Newborn Nutrition. Dalam: Simson KR, Creehan PA. Perinatal Nursing. Philadelphia; Lippincot;1996.

8. Jelliffe DB, Jelliffe EFP. Human Milk in the Modern World, Psychosocial, Nutritional and Economic Significant. Oxford, NewYork, Toronto: Oxford University Press; 1978.

9. Pemda Propinsi Nusa Tenggara Timur. Profil Kesehatan Nusa Tenggara Timur 2002. Kupang: Dinas Kesehatan; 2003.

10. Dawson B, Trap RG. Basic \& Clinical Statistic. Boston, Toronto, Singapore: Lange Medical Books; 2001.

11. Hediger ML, Overpeck MD, Ruan WJ, TroendleJF. Early Infant Feeding and Growth Status of US born Infants and Children aged 4-71 Month, Analysis from the third National Health and Nutrition Examination Survey, 1988-1994. Am J Clin Nutr 2000;72:159-67.

12. Ahmed S, Parveen SD, Islam A. Infant Feeding Practice in Rural Bangladesh: Policy Implications, J Trop Pediatr 1999; 45:37-41.
13. Righard L. Early Enhancement of Successful Breastfeeding. World Health Forum 1996;17:1006-11.

14. Tappero EP, Honeyfield ME. Physical Assesment of the New-born, NICU Link,CA; 1993.

15. Bhaskaram P. The Cycle of Malnutrition and Women's Health. National Institute of Nutrition Hyderabad; 2001. p. 22:4.

16. Moore VM, Davies MJ, Wilson KJ, Worsley A, Robinson JS. Dietary Composition of Pregnant Women is Related to Size of the Baby at Birth. J Nutr 2004;134(7):1820-26.

17. Worthington-Roberts BS. Nutrition During Preganancy and Lactation. Dalam: Mahan MK, \& Arlin MT. Food, Nutrition \& Diet Therapy. Philadelphia: WB.Saunders Company; 1992.

18. Suradi R. Spesifitas Biologi Air Susu Ibu. Sari Pediatri 2001;3(3):134-40.

19. Institut of Medicine. Nutritional During Lactation; Lactation Performance of Mothers with Contrasting Nutritional Status in Rural Kenya. Washington DC: Nation Acedemi Press;1991.

20. Bloss E, Wainaina F, Bailey RC. Prevalence and Predictor of Underweight, Stunting and Wasting among Children Aged 5 and Under in Western Kenya. J Trop Pediatr 2004;50:267-71.

21. Jua'at I, Jahari $A B$, Achadi, Endang L, Putra $H$, Soekirman. Penyimpangan positif Masalah KEK di Jakarta Utara dan di Pedesaan Kabuparen Bogor Jawa Barat. Dalam: Widia Karya Nasional Pangan dan GIZI VII. 2000.

22. Departemen Kesehatan Republik Indonesia. Surat Keputusan Menteri Kesehatan No. 913, tanggal 29 Juli 2002, tentang Angka Kecukupan Gizi yang dianjurkan bagi bangsa Indonesia. 2002.

23. Simondon KB, Simondon F, Costes R, Delaunay F, Diallo A. Breast-feeding is Assosiated with Improve Growth in Length, but not Weight, in Rural Senegales Tolders. Am J Clin Nutr 2003;77:937-42.

24. Dewey KG, Heinig MJ, Nommsen LA, Peerson JM, Lonerdal B. Growth of Breast-fed and Formula Fed Infants from 0 to 18 Months. The DARLING Study. Pediatrics 1992:89:1035-41. 